\title{
Livelihood responses to mangrove deforestation in the northern provinces of Ecuador
}

\author{
Respuestas de subsistencia a la deforestación de los manglares en las provincias \\ del norte de Ecuador
}

\author{
Stuart E Hamilton a*, Sarah Collins ${ }^{b}$ \\ *Corresponding author: ${ }^{a}$ College of William and Mary, Department of Geology, Center for Geospatial Analysis, Swem Library, \\ 400 Landrum Drive, Williamsburg, Virginia, USA, tel.: 01-757-634-7927, sehamilton@wm.edu \\ ${ }^{\mathrm{b}}$ Unaffiliated researcher, Ottawa, Ontario, Canada.
}

\begin{abstract}
SUMMARY
Mangrove forests worldwide are under threat. Ecuador is no exception to this trend, with substantial mangrove deforestation across almost all regions. This paper synthesizes a literature review of Ecuadorian mangroves, a remote sensing analysis of the past and present extent of mangrove forests conducted for another paper, and ethnographic field research conducted in the major estuaries of northern Ecuador to present the role of mangrove wetlands in supporting local livelihoods in Ecuador's coastal communities. This paper takes a macro-micro approach, examining the global questions of mangroves and then discussing the micro situation of mangroves in Ecuador before moving onto estuarine specific profiles. All the major mangrove regions of northern Ecuador are examined with a particular emphasis on deforestation / reforestation trends, the estuarine specific forces driving and responding to these trends, as well as the livelihood response of the impacted communities. The research relies on the most current estimates of mangrove forests as well as historic calculations of mangrove area.
\end{abstract}

Key words: mangrove forests, Ecuador, livelihoods, deforestation, reforestation.

\section{RESUMEN}

Los bosques de manglares en todo el mundo están en riesgo. Ecuador no escapa a esta tendencia, como lo demuestran los altos niveles de deforestación de manglares presentes en casi todas sus regiones. Este artículo está compuesto por: una revisión de los estudios sobre manglares ecuatorianos, un análisis de teledetección de las áreas de manglares presentes y pasadas, y por la investigación etnográfica realizada en los principales estuarios del norte de Ecuador para dilucidar el papel de los manglares para la subsistencia de sus comunidades costeras. Se propone adoptar un enfoque macro-micro con el fin de examinar la problemática global de los manglares, para luego discutir la situación a escala micro de los manglares en el Ecuador y, finalmente, proceder a analizar perfiles de estuarios específicos. Todas las regiones de manglares más importantes del norte de Ecuador son examinados con particular énfasis en las tendencias de deforestación-reforestación y en los factores específicos que producen y responden a dichas tendencias. Asimismo, se presentan las estrategias de subsistencia originadas como respuesta a estas tendencias en las comunidades afectadas. La investigación se basa en las estimaciones más actuales, así como en cifras históricas de la extensión de bosques de manglar.

Palabras clave: bosques de manglares, Ecuador, medios de subsistencia, deforestación, reforestación.

\section{INTRODUCTION}

Mangrove deforestation and the role of economicallyvalued resources from mangrove wetlands in supporting rural livelihoods are documented in academic literature. However, most livelihood analyses are a single spatiotemporal snapshot that often neglects to take into account the changing areas of mangrove forests over space and time. Conversely, most mangrove deforestation studies quantify mangrove change over time and space but fail to account for the change in livelihoods while deforestation is occurring. Additionally, the existing literature lacks information of how communities adapt and respond once deforestation occurs. This paper fills these gaps with a spatiotemporal analysis of mangrove change over time in coastal Ecuador with a focus on the resulting adaptation of local populations as it pertains to traditional livelihoods. Specifically examined is how mangrove forest reliant communities resist, adapt, mitigate, and attempt to reverse the livelihood alterations that arise when mangroves are lost.

The scientific community first recognized the importance of mangrove forests in the late 1960s and early 1970s. Odum and Heald (1972) identified the role of mangrove forests as a driver of biodiversity and food production during their pioneering research on mangroves of the Florida Everglades. Their research demonstrates that mangroves are a keystone mutualist that underpins the entire ecology of an estuarine environment. Prior to this research, mangro- 
ve forests had a reputation as having little ecological, environmental, or economic value. As late as 1974, mangrove forests were seen as having little societal benefit (Lugo and Snedaker 1974). In 1969, the United States Department of Agriculture Soil Conservation Service did not classify mangrove forests as an area suitable for crops, pastures, woodland, wildlife, or any other use (Lugo and Snedaker 1974). Much of the focus on mangroves during this period was on reclamation, which illustrates that society and the scientific community only valued mangroves for what they could be converted into (Ellison and Farnsworth 1996).

Mangrove biodiversity. The view of mangroves as a nuisance or a useless land cover has been slow to retreat but the importance of the mangrove ecosystem is now fully appreciated within the estuarine research community. Mangrove forests are not merely a part of one of the most productive ecosystems on the planet; in many ways, they create these ecosystems by stabilizing the soil and creating a habitat in which other organisms flourish (table 1) (Costanza et al. 1997, Blaber 2007). Although a paucity of studies relating biodiversity to mangrove habitat exists for Ecuador, nearby analyses do exist. For example, in Colombia and the Caribbean, mangrove forests support over 140 bird species, 200 fish species, and many hundreds of terrestrial and marine invertebrates and are the basis for high floral and faunal biodiversity in otherwise low-biodiversity areas of mud and salt flats (Alvarez-León and Garcia-Hansen 2003). Within Ecuador, rivers with mangrove wetlands have been shown to have higher levels of fish biodiversity than those without, although attributing the increased diversity to mangrove presence cannot be conclusively ascribed to mangrove forests (Shervette et al. 2007). The contribution to biodiversity is particularly relevant to Ecuador, west of the Andes to the coast, as this region is described as undergoing a massive extinction of flora and fauna, driven by deforestation, with less than $5 \%$ of all original forest remaining (Dodson and Gentry 1991).

Mangrove forest goods and services. Traditional estuarine communities utilize mangrove forests for firewood, charcoal production, boat building, home construction, natural dyes manufacture, roof thatching and sewage treatment (Tomlinson 1986). Mangrove forests also provide key habitat to important traditional coastal seafood in the form of hundreds of species of fish, crabs, shrimps, bivalves, and gastropods (table 1). Other food provided by mangrove forests include wild honey and edible plants; mangrove forests are a prime habitat for nypa palms that provide sugar and alcohol to traditional communities (table 1). Other traditional uses include the utilization of mangrove litter for animal food, medical plants, tourism, and recreation (table 1). Furthermore, mangrove forests in Asia and Ecuador have been used to raise species such as shrimp for hundreds of years in subsistence aquaculture systems (Jimenez 1989, Naylor et al. 1998). Within Ecuador, such artisanal activity appears to be almost extinct. Traditional utilization of mangrove forests is often conducted in a sustainable manner allowing for harvesting of differing products throughout the year. For all of these reasons, mangrove forests have been called an entrepreneur's dream (Tomlinson 1986), as they produce raw materials from seawater and other renewable sources and pass on these goods to traditional communities.

Many studies have attempted to quantify the economic value of various mangrove ecosystems and to demonstrate that the rapid pace of mangrove deforestation and estuarine disturbance may have been due to the slow realization of the economic valuation of preserved mangrove forests (Blaber 2007). The direct economic benefit of a preserved mangrove forest has been estimated to be $\$ 12,229$ per-year per-hectare in Sri Lanka (Batagoda 2003), \$1,092 per-year per-hectare in Kenya (UNEP 2011), and as high

Table 1. Traditional mangrove forests goods and services (FAO 2004, Siikamäki et al. 2012). Bienes y servicios tradicionales de los bosques de manglares (FAO 2004, Siikamäki et al. 2012).

\begin{tabular}{llll}
\hline \multicolumn{1}{c}{ Direct Food } & \multicolumn{1}{c}{ Wood Products } & \multicolumn{1}{c}{ Mitigation } & \multicolumn{1}{c}{ Other } \\
\hline Wild shrimp & Timber & Flood control & Recreation \\
Wild fish & Charcoal & Shoreline stabilization & Medicinal products \\
Mollusks & Firewood & Wind protection & Animal feed \\
Crab & Boats & Wastewater treatment & Habitat \\
Clam & Stakes and poles & Carbon sequestration and mitigation & \\
Cockles & Home construction & Ground water management & Pollutant treatment \\
Plants (feed and fodder) & Thatch & (aquaculture runoff) & \\
Pollinating bats & Tannin & Ocean/surge protection & \\
Pollinating bees & Pulp & & \\
Sugar (Nipa) & Bark & & \\
Apiculture for honey & & & \\
Alcohol (Nipa) & & & \\
Vinegar & & & \\
Traditional aquaculture & & & \\
Salt & & & \\
\hline
\end{tabular}


as $\$ 751,368$ per-hectare in totality when damaged by oil spill in Puerto Rico (Lewis 1983). The estimated 1994 value of a mangrove swamp was \$9,990 per-hectare per-year with estuaries at $\$ 22,832$ per-hectare per-year (Costanza et al. 1997). This is a global average. A more recent analysis of ecosystem goods and services values mangroves at between \$10,000 and \$35,000 per hectare annually in northern Haiti (Inter-American Biodiversity Information Network 2009). Many of these valuations neglect the carbon offset value of the forests. Even without carbon taken into account, mangrove forests can be seen to offer substantial economic benefits even when compared to cash crops.

Literature on livelihoods in Ecuador, though limited, supports the view of mangrove forests providing numerous goods and services when utilized in a traditional manner. Ecuadorian mangroves have historically been utilized for charcoal and tannin extraction (Snedaker 1986, Labastida 1995). Mangroves also provide a natural wind and flood barrier in addition to providing materials such as timber and poles for the construction of homes (FAO 2004). Indeed, in the northern part of Esmeraldas province, mangrove economy still powers the entire regional economy (Veach 1996, Ocampo-Thomason 2006). Mangroves in Ecuador also contribute to the wider economy. Under the Costanza valuation, the 1969 mangrove forests of Ecuador as determined by CLIRSEN (Centro de Levantamientos Integrados de Recursos Naturales por Sensores Remotos), if preserved, would be producing economic returns of approximately five billion dollars annually (adjusted from 1994 USD to 2000 USD). Such an ecosystem function value of mangroves excludes other potential economic values of mangroves such as carbon sequestration, pollinating species habitat, and use for medicinal purposes.

Mangroves and fisheries. As of 2008, $85 \%$ of the fish stocks monitored by FAO were classified as fully exploited or overly exploited (FAO 2010). Many studies have documented that mangrove wetlands provide essential fish habitat for several economically-valued fish species (Chong 2007, Koenig et al. 2007). Additionally, many species of fish and invertebrates that are important in subsistence fisheries also rely on mangrove wetlands (Ocampo-Thomason 2006, Blaber 2007, Nagelkerken 2007). It is argued that mangrove forests play an important role in fisheries sustainability and global food security by sustaining commercial wild fish populations (Odum and Heald 1972, Naylor et al. 1998, Chong 2007). Therefore, it can be deduced that mangrove deforestation likely contributes to fisheries decline.

The findings that equate fisheries decline with mangrove decline are contested. The opposing argument is that most studies that equate mangrove losses and fisheries decline show correlation but not causation and are plagued by problems of spatiotemporal autocorrelation because commercial over-fishing and mangrove depletion occurred on a similar temporal scale and in similar places (Blaber
2007). Despite this view, numerous other counter-perspectives advocate the importance of mangrove to offshore fisheries. For example, it is estimated that the 567,000 ha of mangrove forests in Malaysia sustain more than half of Malaysia's annual fish catch, totaling 1.28 million tonnes, through larval retention, trophic supply, and habitat support (Chong 2007). Although Blaber (2007) contests the relationship between the decline of offshore commercial fisheries and mangrove deforestation on a global scale, the stance is unequivocal when dealing with traditional fishing communities and their relationship to mangrove by stating that the long-established fishing practices of local estuarine fishermen are entirely dependent on the existence of the mangrove system (Blaber 2007).

Within Ecuador, no peer-reviewed study exists concerning the investigation of what role mangroves play in the life cycle of economically-valued species; although two studies have described the fish communities associated with mangrove wetlands providing anecdotal evidence of the importance of mangroves to Ecuadorian fish species. Shervette et al. (2007) documented the fish community of a heavily disturbed mangrove wetland in Palmar, Ecuador. Juveniles of several snook species were found exclusively in mangrove habitat and not in an adjacent tidal river that lacked mangroves. Although only a small portion of Rio Palmar's mangrove remains intact, it sustains higher fish richness than that sustained by the nearby river lacking mangroves. These results indicate that mangroves in Ecuador may play an important role in sustaining local and regionally important fish species. Other research in Ecuador points to artisanal fishermen utilizing shrimp and other biological resources of mangroves for hundreds of years, noting that the entire lifecycle of shrimp in Ecuador's coastal waters is reliant on mangroves (Cuoco 2005).

\section{METHODS}

The land cover change methods, analysis, and results were found in two accompanying papers (Hamilton 2011, Hamilton and Stankwitz 2012). Ethnographic research, unique to this paper, consisted of 215 household interviews, 25 community surveys and 35 semi-structured interviews. All semi-structured interviews and surveys were conducted during 2009 and involved contacts made during earlier visits to these regions in 2007 and 2008. The semistructured interviews were conducted with approximately 61 local residents and estuarine stakeholders. They took the form of free-flowing conversations with a focus on the past and present livelihood exploitation of mangrove forests. An attempt was made to interview those who make their living in the estuary from traditional goods and services provided by the estuary, those who work on the shrimp farms or in support of shrimp farms that are now the dominant services offered by the estuary and community leaders who had insights about past and present livelihood exploitation of the estuaries. Artisanal fishermen were also 
interviewed as they rely on the natural goods and services of an estuary to make their living. The goal of the interviews was to understand how mangrove deforestation in the estuaries has altered the livelihood and food security options available to those dependent on the wider goods and services of the estuary; in other words, to gain insight into the implications of the mangrove deforestation.

The household survey was comprised of five sections. (i) A household demographic section was created to record important demographic information about household composition $^{1}$. (ii) A household consumption section was created to collect data on household mangrove dependency pertaining to livelihoods. (iii) A household employment section was designed to provide current data on household's wider employment income. (iv) A household access to amenities section was created to provide details on whether or not the family owns items affiliated with the fishing or mangrove industry. For the purpose of this paper, specific details on appliances, automobiles, and boats owned by the household were evaluated. (v) A mangrove/ shrimp employment section evaluated the characteristics of households' livelihood dependency specifically on the mangrove and aquaculture economies. The community survey was comprised of ten sections. These can be classified as aid, natural resource protection, demography, energy use, education, migration, history, recent events, development and agriculture as they pertained to the wider estuarine communities. Both the household and community survey provided important information pertaining to the history of mangrove livelihoods in the study areas defined below (figure 1).

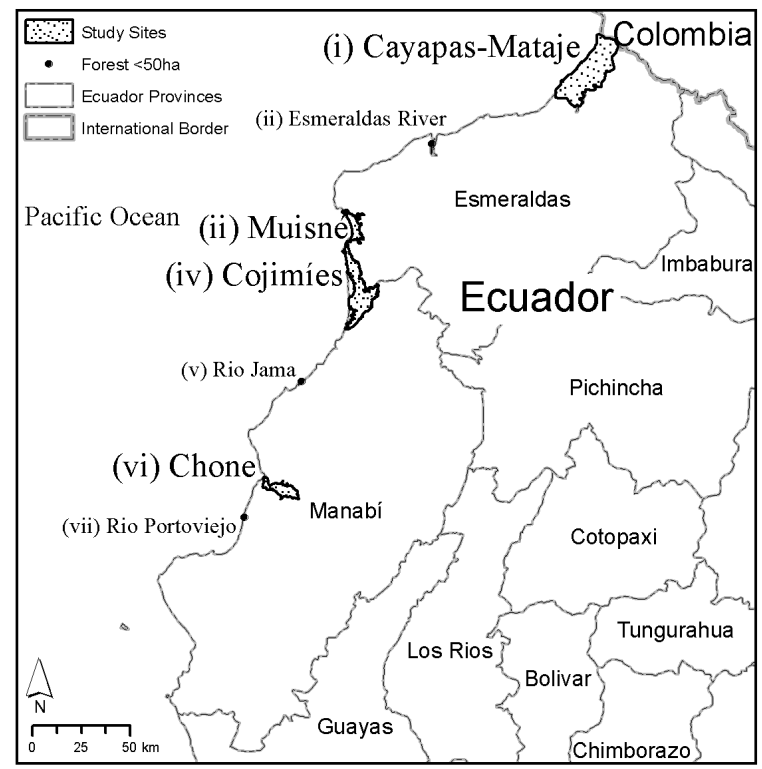

Figure 1. Study areas and minor mangrove forests. Áreas de estudio y bosques de manglares menores.

\footnotetext{
${ }^{1}$ Specific questions included gender, age, education years, neighborhood, household emigration and household immigration. Income was included under employment.
}

Within one study area (Chone), ethnographic research took the additional form of collaborative mapping. This portion of the ethnographic research was based on the recent advancement of participatory research mapping techniques that have shown to be an effective technique to assess resource use and histories among rural communities. Arrangements were made with the local fishing collective to have a group meeting and free flowing discussion driven by poster-sized maps generated from semi-decadal land use within the estuaries. Participants were encouraged to discuss the forces behind the land use change and the implications of such changes to their livelihoods. The participants annotated the maps with symbols representing the various areas of seafood catch throughout time.

Finally, a literature review relating to livelihood options in Ecuador activity resulted in two socioeconomic studies useful for this research. In 2003, Ocampo-Thomason (2006) conducted 170 socioeconomic surveys and 100 interviews with a focus on mangrove dependent livelihoods in Cayapas-Mataje Estuary. Veach (1996) conducted 61 household interviews in and around Cayapas-Mataje. Although focused on gender roles, this research does contain substantial information on the rates of utilization of mangroves goods and services. These socioeconomic studies supplemented the information gained from the primary ethnographic research.

\section{RESULTS}

Esmeraldas province. As of 2000 to 2009 (Giri et al. 2011), mangrove forests exist in four locations within Esmeraldas Province (figure 1). From north to south, these four locations are: (i) a very large forest surrounding and within Reserva Ecológica Cayapas-Mataje at the confluence of the Cayapas, Mataje, and Santiago rivers; (ii) a series of small island and fringe forests near the mouth of the Rio Esmeraldas; (iii) a large forest surrounding and within Muisné Estuary; and (iv) a formerly large but now heavily degraded forest around and within Cojimíes Estuary. This paper will discuss areas (i), (ii), and (iv), which cover over $99 \%$ of the mangrove area in Esmeraldas province and all of the areas where local livelihoods depend on mangroves (figure 1). Area (i) is of particular interest as the mangrove deforestation pattern is different from all other estuaries analyzed. For the purposes of this analysis, the mangroves of Cojimíes (iv) are classified as belonging to Manabí province although the actual forest is split between Esmeraldas and Manabí provinces.

Cayapas-Mataje estuary. The mangrove surrounding and within the 44,000 $\mathrm{km}^{2}$ Reserva Ecológica Cayapas-Mataje is likely the least degraded and most ecologically important in Ecuador and potentially the most pristine forest along the entire pacific coast of the Americas. This region consists of pristine estuary environments, freshwater and inter-tidal flooded wooded wetlands, and wooded peat lands. Cayapas- 
Mataje contains the tallest known mangroves in the world, with heights up to 64 meters (Spalding et al. 2010). The area has special recognition as an original Ramsar site and 18,000 ha of mangrove are protected under national law (001 DE 052-A-DE) within the preserve. Unlike other protected mangrove estuaries to the south, Reserva Ecológica Cayapas-Mataje appears to have strong national standing, with the state, the legal owner of the estuary, and the Ministry of the Environment managing the mangrove resource.

The land use change analysis conducted indicates that mangrove deforestation (table 2) is more limited in Cayapas-Mataje Estuary than any in other location in Ecuador. Ninety-two percent of the pre-aquaculture mangroves remain in the estuary. Local residents and those who rely on wild-catch in the area are aware of the national recognition of the mangrove and strive to protect the mangrove forest; having successfully unified against shrimp farm expansion and mangrove deforestation. As early as 1995, all concheros and $82 \%$ of fishermen in this region described shrimp farming as bad for the community (Veach 1996) and opposed mangrove deforestation. Local residents in Cayapas-Mataje mentioned local resistance against shrimp farming as the reason for mangrove forests survival and several noted that local fishing, concha negra (Anadara tuberculosa (Sowerby 1833), Arcidae, bivalve mollusk) collectives, and community groups have unified to protect mangrove forest in the region. Such community awareness of mangroves and willingness to partake in preservation and management occurs in other regions of the world (Badola et al. 2011).

The local residents who obtain their livelihoods from the estuary, led by the concha negra harvesters, have organized and formed a regional group called Federación de Artesanos Recolectores de Productos Bioacuaticos del Manglar (FEDARPOM). FEDARPOM includes fisherfolk and agriculturalists in an attempt to conserve livelihood resources inside and around Cayapas-Mataje (Ocampo-Thomason 2006). Conflict between FEDARPOM and shrimp farmers occurs but unlike other estuaries, the traditional livelihood users appear to have prevailed. For example, it is reported that concheros have confronted shrimp farmers who try to block their access to concha negra in the estuary. Concheros maintain that even if shrimp farmers legally purchased land for a shrimp farm, what they pur-

Table 2. Mangrove land cover change in Cayapas-Mataje Estuary from pre-aquaculture through 2006.

Cambio de superficies de manglares en el estuario Cayapas-Mataje, desde la época pre-acuícola hasta el 2006.

\begin{tabular}{cccc}
\hline Year & Mangrove (ha) & Aquaculture (ha) & Other (ha) \\
\hline 1986 & 35,144 & 0 & 15,570 \\
1997 & 33,720 & 1,425 & 15,569 \\
2001 & 32,695 & 2,449 & 15,570 \\
2006 & 32,344 & 2,800 & 15,570 \\
\hline
\end{tabular}

chased is the terrestrial land; and that does not give the landowner the rights to the mangroves, to the concha negra alongside their land, or the right to block the concha negra harvesters' access to this resource (Veach 1996).

Numerous reasons likely exist for the preservation of mangroves in Cayapas-Mataje. Local residents generally refer to community organizations and their active resistance as the primary force behind the preservation of the mangrove forest. This community response appears to be motivated by two forces: knowledge of an earlier period of deforestation and the date of aquaculture's arrival in the region. Firstly, almost all residents mentioned learning about the economic importance of mangroves from an earlier period of mangrove deforestation that damaged local livelihoods and depleted wild estuarine fisheries. This is recorded in literature as a government-sponsored industrial program to exploit the mangroves of CayapasMataje for tannin production from the mid-1950s until the late 1960s (Snedaker 1986, Labastida 1995, Spalding et al. 1997, Ocampo-Thomason 2006). Deforestation continued until a collapse in worldwide tannin prices and a switch by timber companies to other environments such as cloud forests and rainforests for tannin. Secondly, local residents pointed to knowledge of the destruction shrimp farms caused further south as a reason for their collective response opposing the shrimp farms. The land use analysis supports these statements. Aquaculture arrived later in CayapasMataje than in any other estuary in Ecuador (Hamilton and Stankwitz 2012). Local residents indicate they knew of the environmental degradation shrimp farms had already caused in estuaries such as Chone, Cojimíes, and particularly in Muisné and resisted accordingly.

The reasons for the survival of mangrove forests in Cayapas-Mataje is likely in part due to local efforts based on livelihoods and culture, however, other physical and geopolitical factors may help explain the high level of forest preservation. One of the primary factors hindering shrimp farm expansion surrounding and within Cayapas-Mataje, thereby preserving mangrove forests, was likely the historic isolation of the region and lack of reliable paved roads connecting Cayapas-Mataje to the rest of Esmeraldas. Indeed, until the 1990s, only an unreliable train or unimproved road connected Cayapas-Mataje to the highlands and no paved roads ran south into Esmeraldas until the mid-2000s. This resulted in difficulty moving heavy equipment into the area to remove mangrove and build shrimp farms and even more difficulty exporting bulk quantities of iced or fresh shrimp out of the region. The primary form of transportation of goods and people in Cayapas-Mataje is dugout canoes. Unlike Cayapas-Mataje, all the estuaries further south are generally well connected via a paved road network to the Ecuadorian commercial centers and ports of Esmeraldas, Manta, Guayaquil, or Machala. Additionally the border region has been in a geopolitical hotspot with Fuerzas Armadas Revolucionarias de Colombia (FARC) rebels and other Colombian groups destabilizing 
the northern Ecuadorian borderlands and hence a poor site for external investment that may have historically driven the mangrove to aquaculture conversion.

The future of mangrove forests surrounding and within Cayapas-Mataje Estuary appears relatively secure due to the combination of community organizations resisting shrimp farms and supporting mangrove forests, federal government support, enforced estuary land use regulations with a focus on preservation, and international recognition. The positive outlook does have some caveats. The transportation hindrance and the geopolitical hindrance to mangrove deforestation and the advance of shrimp aquaculture in Cayapas-Mataje are essentially resolved. The region is now well connected to the road-network and the FARC are in substantial retreat and no longer active in the border areas of the region. These developments could potentially present a challenge to the preservation of the mangroves and mangrove driven lifestyle of Cayapas-Mataje by opening up the region to the global economy and allowing the expansion of aquaculture.

Muisné estuary. The area in and around Muisné has experienced substantial mangrove deforestation with less than $29 \%$ of its 1970 mangrove forest remaining as of 1998 (table 3). Parts of the estuary do have a protected status, such as the Muisné River Estuary Wildlife Reserve but this preserve does not appear to have the national, or even regional, recognition of the Cayapas-Mataje estuary preserve further north. The mangrove economy still has a strong foothold in the region, however. Twenty-eight percent of households interviewed report having a member engaged in the mangrove economy. This is remarkable considering mangrove forests are a small fraction of their original land cover level. The shrimp farm economy in Muisné Estuary, which now covers $300 \%$ more of the estuary than mangrove, employs only $6 \%$ of the local population.

Muisné appears to have adapted to the degradation of the mangrove economy. In addition to local residents obtaining limited livelihoods from the mangrove economy that persists, the area has a small but robust commercial center based on tourism. Local residents who work the estuary report declines in wild-catch and blame mangrove deforestation for the economic hardship of the region. Muisné exhibited other environmental ramifications of

Table 3. Mangrove land cover change in Muisné Estuary from pre-aquaculture through 2005.

Cambio de superficies de manglares en el estuario Muisné, desde la época pre-acuícola hasta el 2005.

\begin{tabular}{cccc}
\hline Year & Mangrove (ha) & Aquaculture (ha) & Other (ha) \\
\hline 1971 & 3,399 & 0 & 3,263 \\
1986 & 3,219 & 167 & 3,276 \\
1998 & 1,000 & 3,277 & 2,385 \\
2005 & 1,065 & 3,212 & 2,385 \\
\hline
\end{tabular}

mangrove deforestation not witnessed elsewhere. The ocean-side portion of the Muisné Estuary $\left(0.561916^{\circ}\right.$, $-80.002440^{\circ}$ ) is exposed to direct wave impacts, whereas other estuaries analyzed are protected from direct wave action. In Muisné, numerous coastal shrimp farms that displaced mangrove forests were breached by storm events. The coastline behind these former forests shows signs of rapid erosion. Rapid and massive erosion during El-Niño driven storm events was reported on the outer-banks of Muisné; as the mitigation effect of a fringe mangrove forest that dissipates wave action and collects sediment has been lost (Federici and Rodolfi 2001). In many areas, this erosion threatens communities.

Reforestation efforts are occurring in Muisné under an Ecuadorian non-governmental organization (NGO) named FUNDECOL (Fundación de Defensa Ecológica de Muisné). This is the highest profile of all mangrove reforestation groups encountered during my time in Ecuador, having international recognition, a fundraising website, and international volunteers. Although advertising itself as a community organization, FUNDECOL appears more along the line of a developed-world advocate NGO. FUNDECOL works alongside groups such as the Environmental Justice Foundation and can often be found referenced in advocacy magazines and journals in the developed world. Interestingly, despite having the most vociferous and wellknown reforestation group in Ecuador, Muisné appears to have experienced relatively little reforestation or mitigation of deforestation as opposed to other Ecuadorian estuaries.

The success of Muisné appears to be founded on the development of an alternate economy based on tourism, limited local ownership and employment on the shrimp farms, and a relatively high proportion of local residents still able to derive a living from the limited remaining mangrove forest. This differs from the other shrimp farms to the south such as Chone or Cojimíes that appear to employ only migrant labor on the farms and have little or no mangrove economy remaining. Major challenges related to erosion, shrimp farm practices and reforestation exist in the community. Much like Cojimíes and Chone, Muisné also had a clear delineation of those most adversely affected by deforestation and those that have managed to avoid the most damaging aspects of the transition. Women (due to the loss of concha negra), those that live in the interior of the estuary (where most of the mangrove loss has occurred), those without boats (unable to access ocean wildcatch), and the poor (those who cannot afford boats, who cannot afford estuarine frontage) appear to be the most adversely affected by the loss of mangrove.

Manabí province. As of 2000 to 2009 (Giri et al. 2011), mangrove forests exist in four locations within Manabí Province (figure 1). From north to south, these four locations are: (iv) a historically large but heavily degraded forest surrounding and within Cojimíes Estuary; (v) an ex- 
tremely small forest at the mouth of a river in Jama; (vi) a historically large but heavily degraded forest surrounding and within the Chone Estuary; (vii) a small forest south of San Clemente at the mouth of the Rio Portoviejo. This paper will discuss areas (iv) and (vi), which cover over 99 $\%$ of the mangrove area in Manabí province and all of the areas where local livelihoods depend on the mangrove.

Cojimíes estuary. The area around Cojimíes has experienced some of the highest levels of mangrove deforestation within northern Ecuador (table 4). In 1998, only $19 \%$ of the 1971 baseline level of mangrove forest remained. By 2006, mangrove forest cover had recovered from less than $19 \%$ to $32 \%$, meaning substantial reforestation had occurred during the 2000s. Although Mache Chindul National Park straddles the estuary, none of the mangrove area falls within this park so the estuary appears to have no protected status. Ongoing recovery efforts are supported by the United States Agency for International Development with the aim of restoring the estuary so that local inhabitants can once again achieve sustainable livelihoods within the estuary (Herrera and Elao 2007).

The traditional mangrove economy appears almost nonexistent in Cojimíes Estuary. This observation seems most true in the southern interior portion of the estuary where shrimp farms are most dominant. A fisherman at the mouth of the estuary near the village of Cojimíes stated that traditional fishermen still exploit offshore waters but not estuarine waters. During my time in this area, the small fishing communities around Cojimíes Estuary appear to be the most impoverished of all study sites and the quality of the estuary livelihoods available is likely the driving force behind poverty. Cojimíes Estuary once had a thriving fishing and concha negra industry that supported the local population. The extreme poverty today is due to the shrimp farm driven decline of the livelihood and food security options that were provided by the mangrove forest (Herrera and Elao 2007). Fisherfolk in the southern portion of the estuary that are not employed on the shrimp farms appear to make a living by combining what limited resources the estuary has to offer with animal husbandry and the farming of small agricultural plots.

Local residents blame the degradation of Cojimíes Estuary almost entirely on mangrove deforestation caused

Table 4. Mangrove land cover change in Cojimíes Estuary from pre-aquaculture through 2006.

Cambio de superficies de manglares en el estuario Cojimíes, desde la época pre-acuícola hasta el 2006.

\begin{tabular}{cccc}
\hline Year & Mangrove (ha) & Aquaculture (ha) & Other (ha) \\
\hline 1971 & 14,269 & 0 & 13,141 \\
1986 & 12,814 & 1,810 & 12,786 \\
1998 & 2,679 & 13,815 & 10,916 \\
2006 & 4,597 & 12,218 & 10,595 \\
\hline
\end{tabular}

by shrimp farm expansion, although other factors played a role. Cojimíes Estuary is surrounded by agricultural land and many of the rivers entering the estuary are diverted for agricultural use, making them dry most of the year, likely starving the mangroves of a fresh water input source. Additionally, unlike the eco-city approach of Chone (below), the tourism present in Muisné or the mangrove economy of Cayapas-Mataje, the residents of Cojimíes appear to have no other livelihood options to replace the traditional estuary livelihoods that have been lost. Finally, it appears that agricultural run-off may be an important factor limiting the productivity of the estuary, although this may be partially due to the loss of the filtration and sediment capture functions formally provided by the mangrove forest. Residents point to an absence of early resistance being due to a lack of knowledge of the aftermath of mangrove deforestation. The future of the mangrove livelihoods in Cojimíes appears extinct as mangrove livelihood rejuvenation would involve the alteration of local agricultural practices, reversing irrigation practices currently in-place, removal of shrimp farms, and an active mangrove replanting agenda. None of these activities are occurring in combination so the success of the United States Agency for International Development livelihood intervention is likely going to be limited.

Chone estuary. The region around Chone Estuary suffered recent catastrophic El Niño and earthquake events and has yet to recover basic services such as potable water. In response to these catastrophes, Bahía de Caráquez at the mouth of Chone Estuary branded itself the ecological city of Ecuador with the goal of becoming the sustainability capital of Ecuador. The Corazón and Fragatas Islands Wildlife Reserve is located in the center of the estuary and the Swedish Nature Conservancy and the US environmental group Planet Drum are both active in and around the estuary. Adding to the hardship of the region is the substantial levels of mangrove deforestation and associated loss of local livelihoods. Chone has experienced rapid mangrove deforestation from 1968 to present (table 5). Mangrove decreased from 4,238 ha in 1968 to 1,035 ha by 2001. Al-

Table 5. Mangrove levels in Chone Estuary from pre-aquaculture through 2006.

Niveles de manglar en Estuario Chone, desde la época pre-acuícola hasta el 2006.

\begin{tabular}{cccc}
\hline Year & Mangrove (ha) & Aquaculture (ha) & Other (ha) \\
\hline 1968 & 4,238 & 0 & 4,506 \\
1977 & 3,850 & 332 & 4,562 \\
1984 & 2,171 & 3,739 & 2,834 \\
1991 & 1,163 & 4,913 & 2,668 \\
2001 & 1,035 & 5,117 & 2,592 \\
2006 & 1,465 & 5,191 & 2,088 \\
\hline
\end{tabular}


ternately, the period from 2001 to 2006 shows mangroves actually recovering in the estuary. This is likely due in part to a special area management plan implemented surrounding and within Chone Estuary. The goal of the plan is to manage land use and activity around the estuary and provide local stakeholders incentives to participate in the recovery of the estuary.

Mangrove deforestation in the Chone Estuary appears to have decreased local livelihood options and food security among traditional fishing populations. The depletion of wild fish stocks in the estuary was the main factor cited in the decline of traditional livelihoods, together with an increase in levels of food insecurity. For example, one interview respondent stated that the depletion of wild fish stocks in the estuary and near-shore areas was due to mangrove deforestation and the advent of shrimp farming, and this was the primary cause of their economic hardship. 'Fish or bust' is the term another respondent used to describe local dependence on estuary catch in Chone. Semi-structured interview respondents on the north side of the Chone Estuary stated that fishing employs approximately $60-80 \%$ fewer families today than in the 1970 s and that it is no longer possible to support a family by only fishing the estuary. Indeed, local fisherfolk reported that they now make approximately $50 \%$ of what they typically made in the 1970s. The lack of seafood catch opportunities not only affects livelihoods but also has an adverse effect on food security to people of this region. Collective fishermen from the Chone Estuary state that by 1990 fishing within the bay had essentially ceased. Again, this ties in well with land use change findings, with 1991 being the apex of mangrove depletion in the estuary (table 5). Chone fisherfolk also indicate they traditionally relied on the estuary mangroves for wood, tannins, charcoal, medicine, and even for making shoes before deforestation; all of these activities are now extinct.

The pathways towards livelihood loss mentioned that cause wild catch decrease include the use of herbicides and pesticides in shrimp farms, the loss of habitat in the mangrove forest, and water quality issues connected to shrimp farm practices such as effluent drainage. It should be noted that shrimp farms themselves may provide habitat to other non-aquatic species once they displace mangrove forest (Cheek 2009). Interview respondents claimed that water quality has declined due to mangrove depletion and shrimp farm practices. This statement is supported in the only peer-reviewed study of water quality in the Chone Estuary. During my three tours of the estuary, weedy growth appeared to be a major problem that was not present in the non-farmed estuaries such as Cayapas-Mataje to the north or those to south of Chone such as the mangroves around San Clemente. It is likely the estuary is suffering from oxygen depletion and high levels of nutrient loading due to the sheer magnitude of shrimp farms that have displaced mangrove forests (Stram et al. 2005). This may be in part due to the loss of the mangrove filter that otherwi- se mitigated terrestrial agricultural runoff. One interview respondent commented that some aquatic species such as crab, conch, and crayfish have disappeared from the estuary altogether. Another respondent noted that offshore fishermen appear to have not fared as badly as those in the estuary and that although catches have declined they seem to be on the rise again. The lack of fishing in the estuary appears to have forced fisherfolk to move from the estuary into offshore waters further increasing demand on an already stressed resource.

All of the fishermen within the Chone Estuary seem to understand the relationship between mangrove forest and wild catch. This was most clearly expressed by the Chone fishing collective members when they stated that they have replanted mangroves on the Isla Corazón, so they can return to fishing the estuary as well as catering to tourists. Various interview respondents stated that it was a lack of local knowledge in the early days of deforestation that prevented them from organizing and resisting the shrimp farms. This lack of knowledge about the impacts of deforestation ties in with the land use analysis and information gleaned from Cayapas-Mataje fishing collectives. Those in communities to the north stated that they resisted shrimp farms, and hence deforestation, due to the fact they had learned of the negative impacts of deforestation from such places as Chone. Fisherfolk in Chone also state that businesspersons who purchased terrestrial lands deceived the fisherfolk after the transactions, which led to mangrove deforestation. The shrimp farm companies purchased terrestrial land and then the purchaser would take ownership of aquatic land on the boundary of the terrestrial purchase and build shrimp farms out into the estuary by removing mangrove forest. This practice was verified by respondents in Cayapas-Mataje who stated this method was employed to get around the fishermen blockade of estuarine-based aquaculture in the region.

Chone's residents react to the land use change occurring in the estuary and are active participants in the estuary restoration that is occurring. At the city-level, activities such as the enthusiastic creation of the eco-city label by the citizens of Chone, the preservation and management status now attached to the estuary, and the recently implemented wild-catch season and wild-catch size rules all demonstrate a commitment to improve and restore the estuary to its former health. A concrete example of this regeneration mindset is found in the land use analysis with Chone Estuary exhibiting robust levels of reforestation of mangroves over the last decade (table 5). The Corazón fishing collective is directly responsible for $90 \%$ of this replanting with other groups including Peace Corps, NGOs and elementary school children responsible for the rest. This replanting appears to be returning the estuary, or at least portions of the ocean-side of the estuary, back into productive fishing grounds. This regrowth area is also a tourist attraction and has become a major frigate bird nesting site. In addition to the reforestation of mangroves, 
the period of shrimp farm expansion in the estuary appears to be at an end. I did witness farms under construction on terrestrial land close to the Chone Estuary that will obtain their water from, and likely drain into, the estuary environment but this appears to be the exception and not the current norm.

Another sign of estuary improvement in the Chone Estuary is the advancement of other livelihood options now that fishing is no longer possible. The national government assists the fishing communities so they benefit from tourism-based livelihoods. During two of my three trips to Chone, I encountered a tourism development officer from Quito who is working among the fisherfolk to develop and assist them with a plan to bring tourists from other areas of South America to the estuary. This official visits every few months to guide the fisherfolk and provides limited amounts of financial support. I observed a number of Chilean tourists at Isla Corazón touring the mangroves with traditional fisherfolk in dugout canoes during my time in this community. Fisherfolk did express that tourism was contributing to the economic health of their community now that mangroves are recovering in the estuary and was an unexpected livelihood boon.

\section{DISCUSSION}

Mangroves are the foundation of one of the most biologically diverse and economically rewarding ecosystems on the planet. Using the metric of biological species richness or the metric of economic return, mangrove forests are under-valued. Mangroves sustain fisheries, provide economic opportunities, provide a secure supply of food to local residents, purify water, trap sediment and nutrients, protect coastlines from natural disasters, provide habitat, and mitigate atmospheric carbon levels. These functions of mangrove forests benefit not only local communities but also the wider world. Although mangroves play a global role, it is at the livelihood level in traditional fishing communities that mangroves are most beneficial. During times of food scarcity, mangrove habitat provides a ready source of freely available protein, in the form of fish and shellfish. During times of fuel shortages, mangroves provide the wood and charcoal necessary to heat water for sanitation and the fuel for cooking. Mangrove timber is used by the coastal populations to construct homes and boats, which are necessary to earn a living. In many regions, insects, birds, and bats of mangroves help to pollinate local agricultural crops. Perhaps most importantly, mangroves stabilize the shoreline by providing solid ground for local plant and tree species to inhabit swamp environments. Mangroves have a visible and immediate effect on local communities, which are also the ones to be most adversely affected by the removal of mangrove forests.

Within coastal Ecuador, mangrove deforestation has unevenly affected the livelihoods of all communities in which it has occurred. This effect is disproportional both geographically, as described in the results, and socioeconomically. Deforestation appears to have adversely affected the poorest members of society more than wealthier members. For example, concheros require direct foot access to a mangrove estuary and concha negra only exists in the mangrove forest. The social customs in northern Ecuador are to preserve concha negra collection positions for women in the community, but deforestation has wholly depleted this resource and shrimp farms have blocked pedestrian access to the bay. In another example, the livelihoods of poorer fishermen without boats are more heavily impacted than livelihoods of wealthier fishermen who access offshore catch by using boats with motors. These poorer fishermen require direct access to the inner estuary that is the most heavily deforested. Additionally, poor fishermen access to the inner estuary is now physically impeded by the shrimp farms. Those that inhabit the inland interior of an estuary are generally poorer than those that reside on the more expensive coastal land. Again, the communities that rely entirely on the mangrove estuary are the ones that suffer the most adverse livelihood and food security impacts of land use conversion.

One of the major differences between mangrove deforestation and other forms of deforestation is the relative depletion of livelihood options and food security associated with mangrove deforestation. For example, rainforest deforestation and mangrove deforestation both result in macroclimate changes, losses of biodiversity and socioeconomic implications for residents that reside in the area. Yet, estuarine mangrove forests are a major food production system with each hectare lost resulting in the loss of many local livelihoods. Other types of forest such as rainforest do not have the same impact on local food production systems per hectare of loss. Indeed, tropical forest have only 6 $\%$ of the food productivity of a tropical estuary, $7 \%$ of the food productivity of a mangrove forest and only $3 \%$ of the food productivity of a mangrove forest and estuary combined (Costanza et al. 1997). Although shrimp farms that displace mangrove forests are a food production system in their own right, they do not create as many food products for the local community, particularly at the artisanal level, as the resource they displace (Naylor et al. 1998).

The results of this analysis support and expand upon earlier livelihood studies conducted in northern coastal Ecuador. In Cayapas-Mataje the major livelihood analysis undertaken by Ocampo-Thomason (2006) concludes that mangroves are particularly important to women and the poor and that shrimp farming is having a largely negative impact on the residents of this region. Veach (1996) predicted this problem, particularly as it pertains to women, but it appears that the shrimp farm resistance movement in Cayapas-Mataje observed by these authors may have turned the tide in this region and resulted in a reversal, or at least halting, of livelihood declines due to aquaculture practices. Within Cojimíes, the summary compiled by Herrera and Elao (2007), as part of an intervention by the 
United States Agency for International Development, discusses the degradation of the estuary and how this has reduced the seafood on which local stakeholders rely. Again, this analysis supports their research findings with the local residents unable to obtain food security from this estuary. Finally, within Chone Stram et al. (2005) concluded that the shrimp to mangrove ratio had passed a critical threshold in the upper estuary and this was causing anoxic conditions within the estuary, which leads to declines in seafood on which local populations rely. Again, these results support this finding but with the caveat that since 2005 local stakeholders have responded and the mangrove is now expanding in this estuary and fishing and associated activities are starting to return as a viable economic activity. No comparative livelihood studies exist for Muisné.

Restoring traditional livelihood options, improving food security, and decreasing poverty among traditional communities in coastal Ecuador are likely dependent on mangrove reforestation within the analyzed estuaries. For reforestation to be successful changes will also be necessary in surrounding agricultural and riverine management practices. The estuaries and mangrove forests of CayapasMataje are an example of how historically depleted resources can return to its former condition and then power an entire local economy through a combination of community organization, government support, and shrimp farm resistance. As depicted in the land cover change analysis, Chone fishermen, Muisné activists and Cojimíes outsiders are currently attempting limited amounts of reforestation in all estuaries. Fortunately, compared to other threatened forest environments, regrowth of mangroves can occur in relatively short periods of time. Newly planted mangrove seedlings begin to reach maturity in twenty years or less, and reforestation can be achieved by direct replanting of mangrove as opposed to undergoing transition through other intermediary land cover stages. The realization of mangrove importance to a traditional fishing lifestyle seems to be understood by the communities within all estuaries. This is demonstrated by the recent active reforestation of mangrove forests in almost all estuaries studied. For this expansion of mangrove forests to be successful, a wider recognition of the importance of mangroves forests to local livelihoods will need to be achieved.

\section{ACKNOWLEDGEMENTS}

Thank you to Clare Stankwitz for translations. Thank you to Sarah Byrd for proofing. Thank you to the Nature Conservancy for ASTER data. Our recognition as always to the USGS for the landsat program. Our acknowledgements to the staff of the IGM in Quito for help in obtaining 1960s and 1970s imagery and maps. We are very thankful with the University of Southern Mississippi, the College of William and Mary, and The University of West Florida for funding portions of this research. Our gratitude to Dr. Souris for elevation data and to Ramon Cedeno, José Eduardo
Ganchozo, Dr. Meyer-Arendt, Sean Conner, Nathan McKinney and Don Hagan for help and assistance in Ecuador.

\section{REFERENCES}

Alvarez-León R, I Garcia-Hansen. 2003. Biodiversity associated with mangroves in Colombia. ISME/GLOMIS 3(1): 1-2.

Badola R, Barthwal S, Hussain SA. 2012. Attitudes of local communities towards conservation of mangrove forests: A case study from the east coast of India. Estuarine Coastal and Shelf Science 96: 188-196.

Batagoda BMS. 2003. The economic valuation of alternative uses of mangrove forests in Sri Lanka. The Hague, The Netherlands. United Nations Environment Programme in Netherlands. 84 p.

Blaber SJM. 2007. Mangroves and fishes: issues of diversity, dependence, and dogma. Bulletin of Marine Science 80(3): 457-472.

Chong VC. 2007. Mangroves-fisheries linkages in the Malaysian perspective. Bulletin of Marine Science 80(3): 755-772.

Cheek MD. 2009. Commercial shrimp ponds versus seminatural mudflats as wading bird foraging habitat in northwest Ecuador. Waterbirds 32: 248-264.

Costanza R, R d'Arge, Rd Groot, S Farber, M Grasso, B Hannon, K Limburg, S Naeem, RV O’Neill, J Paruelo, RG Raskin, P Sutton, Mvd Belt. 1997. The value of the world's ecosystem servies and natural capital. Nature 387: 253-260.

Cuoco L. 2005. Organic aquaculture in Ecuador: a more sustainable solution? Tropical Resources Bulletin 24: 59-65.

Dodson CH, AH Gentry. 1991. Biological extinction in western Ecuador. Annals of the Missouri Botanical Garden 78: 27395.

Ellison AM, EJ Farnsworth. 1996. Anthropogenic disturbance of Caribbean mangrove ecosystems: past impacts, present trends, and future predictions. Biotropica 28(4 Part A): 549-565.

FAO (Food and Agriculture Organization, IT). 2004. Mangrove forest management guidelines (digital edition). In FAO Forestry Paper 117. Rome, Italy. FAO. 320 p.

FAO (Food and Agriculture Organization, IT). 2010. State of World Fisheries and Aquaculture. Rome, Italy. FAO Fisheries and Aquaculture Department. 197 p.

Federici PR, G Rodolfi. 2001. Rapid shoreline retreat along the Esmeraldas Coast, Ecuador: natural and man-induced processes. Journal of Coastal Conservation 7(2):163-170. doi: 10.1007/BF02742478.

Giri C, E Ochieng, LL Tieszen, Z Zhu, A Singh, T Loveland, J Masek, N Duke. 2011. Status and distribution of mangrove forests of the world using earth observation satellite data. Global Ecology and Biogeography 20(1): 154-159. doi: 10.1111/j.1466-8238.2010.00584.x.

Hamilton SE. 2011. Quantifying mangrove deforestation in Ecuador's northern estuaries since the advent of commercial aquaculture. ISME/GLOMIS 9(1): 1-3.

Hamilton SE, C Stankwitz. 2012. Examining the relationship between international aid and mangrove deforestation in coastal Ecuador from 1970 to 2006. Journal of Land Use Science 7(2): 177-202.

Herrera M, R Elao. 2007. Análisis de amenazas a la biodiversidad en el Estuario de Cojimies (Ecuador): identificación de amenazas y oportunidades para el manejo del Estuario de Coji- 
mies y su área de influencia dentro del programa SUCCESS. Narragansett, USA. Centro de Recursos Costeros, Universidad de Rhode Island. 38 p.

Inter-American Biodiversity Information Network. 2009. Rapid assessment of the economic value of ecosystem services provided by mangroves and coral reefs and steps recommended for the creation of a marine protected area Caracol Bay, Haïti. In Organization of American States and InterAmerican Biodiversity Information Network eds. Port-auPrince, Haiti. Fondation pour la Protection de la Biodiversité Marine. 7 p.

Jimenez, R. 1989. Red Tide and Shrimp Activity in Ecuador. In Olsen S and L Arriaga eds. Establishing A Sustainable Shrimp Mariculture Industry in Ecuador. Narragansett, RI: Coastal Resources Center, University of Rhode Island. p. 179-184.

Labastida E. 1995. Diagnóstico económico de las actividades relacionadas con la zona de manglar con énfasis en las unidades de producción camaronera. In Inefan E ed. Estudio de las alternativas de manejo del área comprendida entre los Ríos Cayapas y Mataje, Provincia de Esmeraldas. Appendix 9 (1). Quito, Ecuador. EcoCiencia \& INEFAN. 38 p.

Lewis RR. 1983. Impact of oil spills on mangrove forests. Chap. 19. In Tess HJ ed. Biology and ecology of mangroves. Tasks for vegetation science 8 . The Hague, The Netherlands. Dr. W. Junk Publishers. p. 171-183.

Lugo AE, SC Snedaker. 1974. The ecology of mangroves. Annual Review of Ecology and Systematics 5: 39-64.

Nagelkerken I. 2007, Are Non-Estuarine Mangroves Connected to Coral Reefs Through Fish Migration? Bulletin of Marine Science 80: 595-607.

Naylor RL, RJ Goldburg, H Mooney, M Beveridge, J Clay, C Folke, N Kautsky, J Lubchenco, J Primavera, M Williams. 1998. Nature's subsidies to shrimp and salmon farming. Science 282(5390): 883-884. doi: 10.1126/science.282.5390.883.

Ocampo-Thomason P. 2006. Mangroves, people and cockles: impacts of the shrimp-farming industry on Mangrove communities in Esmeraldas Province, Ecuador. In Hoanh CT,
TP Tuong, JW Gowing, B Hardy eds. Environment and livelihoods in tropical coastal zones: managing agriculturefishery-aquaculture conflicts (Comprehensive Assessment of Water Management in Agriculture Series). Oxford, London. University Press. p. 140-153.

Odum WE, EJ Heald. 1972. Trophic analyses of an estuarine mangrove community. Bulletin of Marine Science 22(3): 671-738.

Shervette VR, WE Aguirre, E Blacio, R Cevallos, M Gonzalez, F Pozo, F Gelwick. 2007. Fish communities of a disturbed mangrove wetland and an adjacent tidal river in Palmar, Ecuador. Estuarine, Coastal and Shelf Science 72(1-2): 115-128. doi: 10.1016/j.ecss02006.10.010.

Siikamäki J, Sanchirico JN, Jardine SL. 2012. Global economic potential for reducing carbon dioxide emissions from mangrove loss. Proceedings of the National Academy of Sciences of the United States of America 109: 14369-14374.

Snedaker SC. 1986. Traditional uses of South American mangrove resources and the socio-economic effect of ecosystem changes. In Kunstadter P, Bird ECF, Sabhasri S, eds. Workshop on man in the mangroves. United Nations University. Tokyo, Japan. p. 102-112.

Spalding M, F Blasco, C Field eds. 1997. World mangrove atlas. Okinawa, Japan. The International Society for Mangrove Ecosystems. 178 p.

Spalding M, M Kainuma, L Collins. 2010. World atlas of mangroves. London, UK. Earthscan. 308 p.

Stram DL, CR Kincaid, DE Campbell. 2005. Water quality modeling in the Rio Chone Estuary. Journal of Coastal Research 21(4): 797-810. doi: 10.2112/011-NIS.1.

Tomlinson PB. 1986. The botany of mangroves. New York, New York. Cambridge University Press. 436 p.

UNEP (United Nations Environment Programme, GE). 2011. Economic analysis of mangrove forests: A case study in Gazi Bay, Kenya. Berlin, Germany. UNEP. p. iii-42.

Veach K. 1996. Gender, resource use, conservation attitude and local participation in mangrove fishing villages in Northern Esmeraldas Province, Ecuador. Gainesville, FL, USA. Center for Latin American Studies, University of Florida. 145 p. 
